\title{
Biogeneration and physico-chemical properties of panchagavya fortified chicken feather vermicompost
}

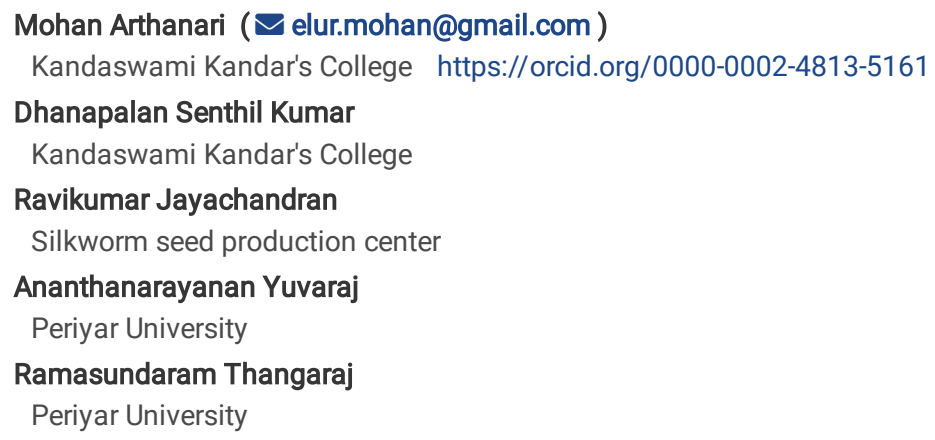




\section{Abstract}

An enormous amount of chicken feather waste materials released by the poultry industry creates severe environmental pollution. Vermicomposting is an eco-friendly way to degrade chicken feather waste along with microbial mixture (Panchagavya). Chicken feather waste was pre-decomposed by mixing it with fresh cow dung (T1), dry cow dung (T2), and Panchagavya (T3). Among these, T3 exhibits rapid deterioration of chicken feather waste and seven combination T3 substrates (E0-E6), taken for the vermicomposting process by Eudrilus eugeniae in 60 days. Scanning Electron Microscopy/Energy Dispersive Spectroscopy (SEM-EDS) and Fourier Transforms Infrared (FT-IR) Spectroscopy are used to assess compost maturity. The result shows that E1 (0.050:1 ratio) shows various functional groups, rich nutrients, and necessary acids than other combinations. For large-scale commercial vermistabilization of chicken feather waste, the E1 combination is suitable for manure production and thereby enhances soil fertility, agricultural production

\section{Introduction}

In the twenty-first century, the utilization of poultry-based products (e.g., eggs and meat) has drastically increased in Asian and European countries. Meat (chicken) is a common source of protein for children and adults. Consequently, the poultry industry is a rapidly growing industry worldwide and economically profitable (Oakley et al. 2014). About 24,000 million tons (MT) of broiler chickens are killed per annum, producing 8,500 MT of chicken feathers globally. In addition, around 350 MT of chicken feathers is eliminated during the meat process by the Indian poultry industries (Agrahari and Wadhwa 2010). The poultry feathers contain $90 \%$ of keratin proteins, $1 \%$ of lipids, as well as $8 \%$ of water (Tesfaye et al. 2017). The keratin is divided into two groups - (i) alpha-keratin, and (ii) beta-keratin (Bodner 1982), and cross-linked polypeptide chains (Gupta and Ramnani 2006). Apart from these, poultry feathers consist of several nutritive elements and pathogenic microorganisms. Improper disposal of poultry feathers creates severe environmental pollution, particularly water and soil pollution. Therefore, there is an urgent requirement for disposal technologies to minimize poultry feather wastes. Recently, vermicomposting employing different earthworm species has grasped the attention of environmental researchers.

The soil bio-indicators, particularly earthworms (Wang et al. 2020), can effectively break down several organic waste materials (Yuvaraj et al. 2020). In general, the vermicomposting operation involves the earthworm species and various microbial communities (Domínguez et al. 2019). The earthworms utilize the different polluted organic waste materials. The earthworms significantly alter the wastes through rapid rotation and aeration and stimulate the degradation of substrate waste materials through various digestive enzymes (Maboeta and Van Rensburg 2003). For example, the gut of the earthworms and gut-related symbionts secrete numerous enzymes, including cellulose, protease, phosphatase, amylase, urease, manase, and lipase, which efficiently stabilize the different waste materials (Ravindran et al. 2015; Gusain and Suthar 2020). The epigeic earthworm species can mainly stabilize the complex waste materials than other anecic and endogeic species, as documented by (Ravindran et al. 2021). For instance, several researchers successfully employed epigeic earthworms, such as Perionyx excavatus, Eisenia fetida, Eisenia andrei, and Eudrilus eugeniae (Yuvaraj et al. 2018, 2020). Undoubtedly, vermicomposting can degrade poultry feather waste materials, which provide the essential nutritive elements that trigger crop production. Experiments of Mazotto et al. (2011) concluded that the biodegradation of poultry feathers waste employing various microbes Bacillus licheniformis 1269 , Bacillus subtilis 1271, and Bacillus cereus 1268 resulted in the production of nutrient-rich substrate. Likewise, Vasileva-Tonkova et al. (2009) reported that several thermo-actinomycete strains effectively degraded the complex poultry feathers, and a considerable amount of soluble protein was increased in the final substrate. The study of Mohan and Senthilkumar (2019) indicated that the composting of poultry feathers and physicochemical parameters significantly increased on the 90th day. According to the previous bench-scale reports, various microorganisms have been used to degrade poultry feather waste materials, but those methods contain several disadvantages like $\mathrm{pH}$ altering the microbial activities, odor production, and slow decomposition process Also, only minimal work has been done concerning vermicomposting of poultry feather wastes. The main objectives of the present study were: (i) to collect the feather wastes from the poultry farms of Namakkal District, Tamil Nadu; (ii) to prepare the Panchagavya (microbial mixture) for precomposting/fortification of the feather waste materials; (iii) to achieve vermicomposting of the feather wastes (pre-composted) employing Eudrilus eugeniae and to evaluate the physicochemical parameters.

\section{Materials And Methods}

\section{Collection of chicken feather waste}

The chicken feather wastes were collected from poultry farms in Elur, Namakkal District (Latitude $11^{\circ} 21^{\prime} 08.72$ ' $\mathrm{N} / \mathrm{Longitude} 78^{\circ} 06^{\prime} 30.43 \mathrm{E}$ ), Tamil Nadu, India. The chicken feather wastes were packed in polythene bags and brought to our laboratory.

\section{Preparation of Panchagavya}

Cow dung $(7 \mathrm{~kg})$ and ghee $(1 \mathrm{~kg})$ were combined in a plastic container with a volume of 80 liters, kept for three days, and periodically stirred two times per day as adopted by Selvaraj (2006). After three days, 10 liters of cow urine, 2 liters of curd, 3 liters of cow milk, 3 liters of tender coconut water, 10 liters of water with $3 \mathrm{~kg}$ of jaggery, and 12 liters of well-ripened bananas were mixed twice a day for 15 days. After the filtration process through a delicate fabric, the Panchagavya was prepared according to Rakesh et al. (2017) and Sarkar et al. (2014) for fortication.

\section{Predecomposition process of chicken feather waste}

Fresh chicken feather waste materials are harmful to earthworm species; therefore, the pre-decomposition process was essential before the vermicomposting process. With optimum environmental factors, the collected chicken feather waste was stored in three earthen pit bags $(150 \mathrm{~cm} \times 45 \mathrm{~cm} \times$ $30 \mathrm{~cm}$ ). Three pre-decomposition treatments (triplicate), namely T1 - fresh cow dung along with chicken feather waste (100gm / liter of water); T2 - dry cow dung and chicken feather waste (100gm/1 liter of water); T3 - Panchagavya mixed with chicken feather waste (100ml/ 1 liter of water). Earthen pit 
bags were sprinkled with water once every two days and turned up every ten days. In general, cow dung and Panchagavya contain various microbial communities which effectively degrade the fresh chicken feather waste.

Furthermore, the microbes of Panchagavya (T3) effectively stabilize the chicken feather waste material at the end of the 60 th day, presented in Figure 1. Other treatments (e.g., T1 and T2) obtained a moderate level of decomposition rate. Hence, T3 substrate materials have been used for further vermicomposting operations.

\section{Experimental configuration of vermicompost}

The pre-decomposed substrate T3 was combined with cow dung in various ratios, viz. E0, E1, E2, E3, E4, E5, and E6, as described in Table 1, and was subjected to vermicomposting using Eudrilus eugeniae, commonly known as the African nightcrawler (Kinberg 1867). An experimental ratio was used for five $\mathrm{kg}$ of substrate mixture in plastic containers $(25 \mathrm{~cm}$ in diameter and $40 \mathrm{~cm}$ in height). Furthermore, adult $E$. eugeniae of 25 numbers was released into the plastic containers. Experimental containers were kept in a cool dark place and protected by a mosquito net. Humidity was maintained at 60 to 80 percent (\%) during the vermicomposting process.

\section{Analysis of physicochemical properties}

Standard methods have been used for the study of physicochemical parameters of pre-decomposed and vermicompost samples. Temperature, $\mathrm{pH}$, and humidity were analyzed at intervals every ten days. At the end of the $60^{\text {th }}$ day, the $\mathrm{pH}$, temperature, organic carbon, organic matter, and ash content of the vermicompost (E0-E6) samples were recorded. The determined $\mathrm{pH}$ was 1:10 (w/v) ratio of using a double-distilled water suspension of compost, and after 30 minutes of mechanical stirring, filtered through Whatman No.1 paper and analyzed by digital pH meter (Vasanthi et al. 2014). The moisture content of the vermicompost samples was oven-dried at $105^{\circ} \mathrm{C}$ until it reached a constant weight (Kato and Miura 2008; Mohee et al. 2008; Unmar and Mohee 2008), and the moisture percentage was calculated using the procedure adopted by Schwab et al. (1994). The dry ash method calculated the ash content (Mohee et al., 2008; Unmar and Mohee, 2008). Total Organic Carbon (TOC) was examined by mixed samples (5g) into the crucibles and then burned for two hours in a furnace at $550^{\circ} \mathrm{C}$ or until no stains of black carbon particles were formed and tested in compliance with Mohee et al. (2008).

\section{SEM-EDS and Fourier-Transform Infrared Spectroscopy}

To analyze the surface and structural morphology of the experimental chicken feather waste (or) vermicompost, a Field Emission Scanning Electron Microscope (FESEM) was used. In the 4000-400 cm-1 frequency range on a Brucher FT-27 FT-IR spectrometer fitted with software from OriginPro, an infrared Fourier (FT-IR) spectrum of the feather waste vermicompost samples was analyzed. A selection of $1 \mathrm{mg}$ was combined with $100 \mathrm{mg} \mathrm{KBr}$ of spectroscopic grade and $1 \mathrm{MPa}$ in pellets.

\section{Statistical analysis}

Statistical analysis was conducted using SPSS software version 26. One-Way ANOVA and Duncan Multiple Range Experiments (DMRT) were analyzed for a homogeneous data set with various parameters in pre-decomposed and vermicomposted samples of the chicken feather waste. All values at $p<0.05$ are considered statistically significant.

\section{Results And Discussion \\ Decomposing of chicken feathers waste}

The Panchagavya consists of various materials such as cow dung, cow urine, curd, cow milk, tender coconut water, jaggery, and bananas, which strongly stimulate the microbial populations in treatments. For example, the study of Amalraj et al. (2013) demonstrated that Panchagavya contains an affluent population of actinomycetes, various bacteria, and P-solubilizers. These microbial communities effectively stabilize the complex chicken feathers waste materials during the pre-degradation process, as depicted in Table 2. The present study demonstrates that Panchagavya contains different essential nutrients that can trigger microbial populations by fortification with substrate. Recently, Behera and Ray (2021) confirmed that various acids (e.g., malic, lactic, citric, acetic, and succinic acids) had been found in Panchagavya, which plays a pivotal role in the elimination of various soil contaminations and enhances the degradation process.

\section{The temperature of the substrate}

Analysis of temperature in composting units is essential to determining the maturity of the final substrate materials. The highest level of temperature was recorded in $\mathrm{T} 3\left(39.63^{\circ} \mathrm{C}\right)$ followed by $\mathrm{T} 2\left(30.23^{\circ} \mathrm{C}\right)$ and $\mathrm{T} 1\left(29.47^{\circ} \mathrm{C}\right)$, respectively. The substrate temperature significantly increased during the middle stage of composting the process, and the declining temperature level was recorded at the end of the experiment. During the decomposition process, heat is eliminated through oxidative action of various microbial communities on waste materials resulting in a decline in temperature in treatments (Peigne and Girardin 2004).

\section{Moisture}

Higher moisture content was recorded in pre-decomposed chicken feather waste materials, indicating the deterioration process progression. The highest percentage of moisture recorded in T1, T2, and T3 was $85.65 \%, 83.50 \%$, and $75.78 \%$, respectively. The subsequent ten days of moisture were improved in T1 (88.43\%) and T2 (86.36\%). From the $60^{\text {th }}$ day onwards, T3 $(16.81 \%)$ of moisture significantly (at $\left.p<0.05\right)$ decreased. During the feather composting 
process, moisture loss was detected, which might be due to the metabolic behavior of the species that encourage heat energy or environmental factors such as airflow over ventilation (Hogan et al. 1989). A drop in moisture content $<30 \%$ triggers the treatment's biological processes, and $50-60 \%$ of moisture content is optimum for the composting process (Castillo 2004).

\section{$\mathrm{pH}$}

The $\mathrm{pH}$ of the substrate is also an essential factor in enhancing the composting process. In the present study, there was a significant increase in the pH of the substrate. A maximum pH was recorded in T2. In the present study, a pH of 6.0-7.0 triggered bacterial growth. Experiments by Pan and Sen (2013) demonstrated that a $\mathrm{pH}$ range of 6.5 to 8.0 was satisfactory for microbial growth in food wheat straw composting. This $\mathrm{pH}$ is one of the critical factors for the degradation of chicken feather waste. On the other hand, the substrate of the T3 had low pH (6.16) because T3 contained Panchagavya, which also effectively degraded the feather waste materials.

\section{Vermicomposting of chicken feather waste materials and earthworm's mortality}

Earthworms significantly stabilize the pre-decomposed chicken feather waste materials. Notably, the gut wall of the earthworms and several symbionts secrete different digestives enzymes which effectually break down the chicken feather waste materials.

The earthworm mortality in experimental vermicomposting bins is presented in Table 3. Earthworm mortality was observed during the initial stages of the vermicomposting operation, and a maximum mortality rate was recorded in E5 and E6. Furthermore, zero percent of the mortality rate was observed in E0 and E1. According to our results, E1 (cow dung and 50gm pre-decomposed chicken feather waste) is suitable for nutrient-rich vermicompost production. Generally, the dried chicken feathers contain $91 \%$ of protein (Salminen and Rintala 2002). Protein-rich organic waste materials can release acidic compounds during the breakdown process (Steve 2017), which may affect the earthworm survival rate, as reported by Francesca (2017).

\section{Physicochemical features of vermicomposting}

With the progression of the vermicompost, the moisture content of the different combinations (CD with CFW) was improved, as described in Table 1. During the vermicomposting process, the percentage of vermicompost moisture (CD and CFW combinations) ranged from 59.89\% to 75.77\% (Table 4 ). The rapid development of various microbial communities may regulate the moisture content of substrate materials. Earthworm species quickly utilize the moistened waste materials. A reduction of $\mathrm{pH}$ in E5 (5.74) and a significantly at $(p<0.05)$ improved level of $\mathrm{pH}$ were recorded in E1 (7.42) and E2 (7.49). The $\mathrm{pH}$ of the substrate decreases by the release of organic acids at the initial stage of decomposition (Liu et al., 2011), and bioconversion of organic nitrogen into free ammonia raises the $\mathrm{pH}$ of the compost (Altieri et al. 2011).

The organic carbon $(\mathrm{OC})$ and organic matter (OM) from earthworm worked treatments are gradually reduced during the vermicomposting process. A maximum $\mathrm{OC}$ and $\mathrm{OM}$ reduction was recorded in $\mathrm{E} 6$. The repaid decrease of $\mathrm{OC}$ might be due to the release of $\mathrm{CO}_{2}$ from the substrate by the joint action of earthworms and various microbial communities (Prakash and Karmegam 2010). Suthar (2006) stated that reducing OC in the vermicomposting process is also responsible for microbial respiration.

\section{Maturity analysis of substrate through Scanning Electron Microscopy (SEM)}

For the surface morphological characterization of substrate materials, SEM is one of the appropriate methods. The final vermicompost micrographs (Figure 2) indicate the smooth surface area and substantially reduce the size of the particles. In the SEM images of E0 and E1, smaller aggregates than E2, E3, E4, E5, and E6 found larger structural surface particles. Similar results were reported by Ravindran et al. (2008) and Senthil Kumar et al. (2014). Ferrarezi et al. (2013) have observed smooth semi-crystalline structured particles from composted chicken feather waste materials. Multiple workers (AlMusallam et al. 2013; Chaturvedi et al. 2014; Jeong et al. 2010a, 2010b) detected microbes' circular and elliptical shape during the chicken feather deterioration.

\section{Nutrient Analysis (SEM-EDS)}

SEM-EDS suitable instruments to detect the various chemical elements (e.g., Ca, C, K, Cl, Mo, Fe, P, Na, Mg, N, S, Mn, Cr, and Co) from the substrate materials are presented in Table 5. The lowest carbon content was recorded in E0 (9.58\%) and E1 (10.74\%). Loss of TOC was achieved by the respiration of microorganisms and the consumption of organic compounds by microorganisms and earthworms (Sharma and Garg 2017). The final vermicompost contained a rich amount of essential macronutrients, such as N (E1-1.24\%), P (E0-4.33\%), K (E0-7.43\%), Ca (E3-34.48\%), and Mg (E5-1.20\%). Nayak et al. (2013) reported that many essential plant-based micronutrients increase during the vermicomposting process. Apart from this, the final substrate materials contain a low level of toxic heavy metals. Lee (1985) indicated that an enormous amount of heavy metal ions could bio-accumulate in the earthworm species' internal tissue (e.g. chlorogogen tissue). The body of the earthworm contains metal-binding protein like metallothionein that effectively binds with several heavy metal ions, resulting in a minimum amount of metals found in the earthworm-treated substrate (Cherian and Nordberg 1983; Hait and Tare 2011).

\section{FT-IR}

Maturity/stability assessment was done through the FT-IR spectroscopy technique. Based on FT-IR spectroscopic techniques, the normal distribution of absorption bands in the vermicomposting samples was observed. Similar results were documented by Fleming and Williams (2019). The FT-IR spectrum of vermicomposting samples is depicted in Figure 3. 
The notable peaks were recorded in E5 $\left(3774 \mathrm{~cm}^{-1}\right)$ and E6 $\left(3848 \mathrm{~cm}^{-1}\right)$, which strongly contain the N-H variety of amide compounds, and it was also confirmed by Purandaradas et al. (2018). A medium sharp peak indicated alcohol and phenol groups, as Kumar et al. (2013) documented. The amount of lower peak strength for $\mathrm{CH}_{3}, \mathrm{CH}_{2}$, and $\mathrm{CH}$ at 2920-2991 cm-1 in vermicompost samples suggested a decline in the level of alkane compounds (Mothé et al., 2018). The suggestion of a diminishing pattern of aliphatic $\mathrm{C}-\mathrm{H}$ stretching at $2936-2958 \mathrm{~cm}^{-1}$ supported the degradation of lipids and carbohydrates from substrate materials (Bhat et al., 2017). $\mathrm{C}=\mathrm{O}$ and S-H stretching vibration of carbonyl and Mercaptans suggested the presence of two distinct weak stretches at $2425-2426 \mathrm{~cm}^{-1}$ and $2519 \mathrm{~cm}^{-1}$. The peak at $1517 \mathrm{~cm}^{-1}$ correlated to the characteristics of the amine groups (Amide-II) from waste materials (Mothé et al. 2018). Various heights at $1417-1422 \mathrm{~cm}^{-1}$ might be due to the presence of carboxylic acid. The peak of $1460-1420 \mathrm{~cm}-1 \mathrm{corresponded} \mathrm{to} \mathrm{the}$ vibration of lignin in the area, and $1100 \mathrm{~cm}-1$ reflected the cellulose and hemicellulose C-O stretch (Mothé and De Miranda 2009). The broad peaks of $1041-1093 \mathrm{~cm}^{-1}$ were associated with anhydride, primary alcohol, and secondary alcohol stretching of CO-O-CO, S = O C-0. Furthermore, peaks of 1047$1091 \mathrm{~cm}^{-1}$ relatively humic acid content in compost and vermicompost (Kumar et al. 2015). The peak at $874 \mathrm{~cm}^{-1}$ is known to be the esters of the S-OR stretching group. The S-S bonds were absorbed adequately at the height of around $537-599 \mathrm{~cm}^{-1}$, as confirmed by Wojciechowska et al. (1999) and Vasconcelos et al. (2008). Nitrogen-containing compounds in their infrared spectrum improved very distinctive absorption lines. C-N-C deformation was caused by mild to heavy bands at 580-418 cm-1 (Rastogi 1991).

During the biodegradation process, a substantial amount of cysteine in the chicken feathers produced a considerable $\mathrm{NH}_{3}$. The feather bi-sulfide cysteine was broken into a stable secondary keratin structure (Wang et al. 2000). Earthworms' combined microbial and digestive enzymes efficiently broke down the complex feather waste materials and produced the nutrient-rich vermicompost (Zhang et al. 2000; Aira et al. 2007).

\section{Conclusion}

Our results strongly suggest that Eudrilus eugeniae and fortification with beneficial microbes of Panchagavya convert the chicken feather waste materials into nutrient-rich vermicompost. Among the various amendment combinations, 0.050:1 ratio (E1) of chicken feather waste to cow dung provides a significant result in compost maturity and nutrient status and reduces environmental contamination from chicken feather waste materials. Therefore, this combination (E1) can be used for large-scale vermistabilization of chicken feather waste materials to enhance soil fertility and agricultural plant production.

\section{Declarations}

\section{Ethics approval and consent to participate}

Not applicable

\section{Consent for publication}

Not applicable

\section{Availability of data and materials}

Not applicable

\section{Competing interests}

The authors declare that they have no competing interests

\section{Funding}

No funding support

\section{Authors' contributions}

MA gave the idea and prepared the outlines and draft of the manuscript. DSK, RJ, AY, and RT designed the figures along with comprehensive tables along with critical editing and reviewing of the whole manuscript. All the authors have read and approved the final version.

\section{References}

Agrahari S, Wadhwa N (2010) Degradation of chicken feather a poultry waste product by keratinolytic bacteria isolated from dumping site at ghazipur poultry processing plant. Int J Poult Sci 9:482-489. https://doi.org/10.3923/ijps.2010.482.489

Aira M, Monroy F, Domínguez J (2007) Earthworms strongly modify microbial biomass and activity triggering enzymatic activities during vermicomposting independently of the application rates of pig slurry. Sci Total Environ 385:252-261. https://doi.org/10.1016/j.scitotenv.2007.06.031

Al-Musallam AA, Al-Gharabally DH, Vadakkancheril N (2013) Biodegradation of keratin in mineral-based feather medium by thermophilic strains of a new Coprinopsis sp. Int Biodeterior Biodegrad 79:42-48. https://doi.org/10.1016/j.ibiod.2012.11.011 
Altieri R, Esposito A, Nair T (2011) Novel static composting method for bioremediation of olive mill waste. Int Biodeterior Biodegrad 65:786-789. https://doi.org/10.1016/j.ibiod.2011.05.002

Amalraj ELD, Kumar GP, Ahmed SMH, Abdul R, Kishore N (2013) Microbiological analysis of panchagavya, vermicompost, and FYM and their effect on plant growth promotion of pigeon pea (Cajanus cajan L.) in India. Organic Agriculture 3(1):23-29. https://doi.org/10.1007/s13165-013-0042-2

Behera S, Ray RC (2021) Bioprospecting of cow-dung microflora for sustainable agricultural, biotechnological and environmental applications. Current Research in Microbial Sciences 2:100018. https://doi.org/10.1016/j.crmicr.2020.100018

Bhat SA, Singh J, Vig AP (2017) Instrumental characterization of organic wastes for evaluation of vermicompost maturity. J Anal Sci Technol 8. https://doi.org/10.1186/s40543-017-0112-2

Bodner GM (1982) Biochemistry, Second Edition. J Chem Educ 59:246. https://doi.org/10.1021/ed059pa246.1

Castillo JV (2004) Inoculating composted pine bark with beneficial organisms to make a disease suppressive compost for container production in Mexican forest nurseries. Nativ plants journal 5:181-185. https://doi.org/10.2979/NPJ.2004.5.2.181

Chaturvedi V, Bhange K, Bhatt R, Verma P (2014) Production of kertinases using chicken feathers as substrate by a novel multifunctional strain of Pseudomonas stutzeri and its dehairing application. Biocatal Agric Biotechnol 3:167-174. https://doi.org/10.1016/j.bcab.2013.08.005

Cherian MG, Nordberg M (1983) Cellular adaptation in metal toxicology and metallothionein. Toxicology 28:1-15. https://doi.org/10.1016/0300483X(83) $90101-4$

Domínguez J, Aira M, Kolbe AR, Gomez-Brandon M, Perez-Losada M (2019) Changes in the composition and function of bacterial communities during vermicomposting may explain beneficial properties of vermicompost. Scientific reports 9(1):1-11. https://doi.org/10.1038/s41598-019-46018-w

Ferrarezi MMF, de Oliveira Taipina M, da Silva LCE, Gonçalves MdoC (2013) Poly (Ethylene Glycol) as a Compatibilizer for Poly (Lactic Acid)/Thermoplastic Starch Blends. J Polym Environ 21:151-159. https://doi.org/10.1007/s10924-012-0480-z

Fleming I, Williams D (2019) Spectroscopic Methods in Organic Chemistry. Springer International Publishing. https://doi.org/10.1007/978-3-030-18252-6

Francesca (2017) The Complete Guide to Protein Poisoning in the Worm Bin. Sauirm Firm. https://thesquirmfirm.com/protein-poisoning-worm-bincomplete-guide/ (accessed 3.30.20).

Gupta R, Ramnani P (2006) Microbial keratinases and their prospective applications: An overview. Appl Microbiol Biotechnol 70:21-33. https://doi.org/10.1007/s00253-005-0239-8

Gusain R, Suthar S (2020) Vermicomposting of duckweed (Spirodela polyrhiza) by employing Eisenia fetida: changes in nutrient contents, microbial enzyme activities and earthworm biodynamics. Bioresour Technol 311:123585. https://doi.org/10.1016/j.biortech.2020.123585

Hait S, Tare V (2011) Vermistabilization of primary sewage sludge. Bioresour Technol 102:2812-2820. https://doi.org/10.1016/j.biortech.2010.10.031

Hogan JA, Miller FC, Finstein MS (1989) Physical Modeling of the Composting Ecosystem. Applied Environmental microbiology 55(5):1082-1092

Jeong JH, Jeon YD, Lee OM, Kim JD, Lee NR, Park GT, Son HJ (2010a) Characterization of a multifunctional feather-degrading Bacillus subtilis isolated from forest soil. Biodegradation 21:1029-1040. https://doi.org/10.1007/s10532-010-9363-y

Jeong JH, Lee OM, Jeon YD, Kim JD, Lee NR, Lee CY, Son HJ (2010b) Production of keratinolytic enzyme by a newly isolated feather-degrading Stenotrophomonas maltophilia that produces plant growth-promoting activity. Process Biochem 45:1738-1745.

https://doi.org/10.1016/j.procbio.2010.07.020

Kato K, Miura N (2008) Effect of matured compost as a bulking and inoculating agent on the microbial community and maturity of cattle manure compost. Bioresour Technol 99:3372-3380. https://doi.org/10.1016/j.biortech.2007.08.019

Kinberg JGH (1867) Annulata nova. Öfersigt af Kungliga Svenska Vetenskaps-Akademiens förhandlingar. Stockholm 23:97-103

Kumar DS, Kumar PS, Rajendran NM, Anbuganapathi G (2013) Compost maturity assessment using physicochemical, solid-state spectroscopy, and plant bioassay analysis. J Agric Food Chem 61:11326-11331. https://doi.org/10.1021/jf4034943

Kumar MS, Rajiv P, Rajeshwari S, Venckatesh R (2015) Spectroscopic analysis of vermicompost for determination of nutritional quality. Spectrochim Acta Part A: Molecular Biomolecular Spectroscopy 135:252-255. https://doi.org/10.1016/j.saa.2014.07.011

Lee K (1985) Earthworms: their ecology and relationships with soils and land use. Academic Press Inc

Liu D, Zhang R, Wu H, Xu D, Tang Z, Yu G, Xu Z, Shen Q (2011) Changes in biochemical and microbiological parameters during the period of rapid composting of dairy manure with rice chaff. Bioresour Technol 102:9040-9049. https://doi.org/10.1016/j.biortech.2011.07.052 
Maboeta MS, Van Rensburg L (2003) Vermicomposting of industrially produced woodchips and sewage sludge utilizing Eisenia fetida. Ecotoxicology Environmental safety 56(2):265-270. https://doi.org/10.1016/S0147-6513(02)00101-X

Mazotto AM, de Melo ACN, Macrae A, Rosado AS, Peixoto R, Cedrola SM, Couri S, Zingali RB, Villa ALV, Rabinovitch L, Chaves JQ (2011) Biodegradation of feather waste by extracellular keratinases and gelatinases from Bacillus spp. World Journal of Microbiology Biotechnology 27(6):1355-1365. https://doi.org/10.1007/s11274-010-0586-1

Mohan A, Senthil Kumar D (2019) Quantification of $\beta$-carotene, lycopene, and chlorophyll content in tomato fruits of enrichment of chicken feathers composting. Int J Recycl Org Waste Agricult 8:473-477. https://doi.org/10.1007/s40093-019-0258-6

Mohee R, Driver MFB, Sobratee N (2008) Transformation of spent broiler litter from exogenous matter to compost in a sub-tropical context. Bioresour Technol 99:128-136. https://doi.org/10.1016/j.biortech.2006.11.040

Mothé CG, De Miranda IC (2009) Characterization of sugarcane and coconut fibers by thermal analysis and FTIR. J Therm Anal Calorim 97:661-665. https://doi.org/10.1007/s10973-009-0346-3

Mothé MG, Viana LM, Mothé CG (2018) Thermal property study of keratin from industrial residue by extraction, processing and application. J Therm Anal Calorim 131:417-426. https://doi.org/10.1007/s10973-017-6845-8

Nayak A, Varma V, Technol AK (2013) Effects of various C/N ratios during vermicomposting of sewage sludge using Eisenia fetida. Environ Sci Technol 6:63-78. https://doi.org/10.3923/jest.2013

Oakley BB, Lillehoj HS, Kogut MH, Kim WK, Maurer JJ, Pedroso A, Lee MD, Collett SR, Johnson TJ, Cox NA (2014) The chicken gastrointestinal microbiome. FEMS Microbiol Lett 360(2):100-112. https://doi.org/10.1111/1574-6968.12608

Pan I, Sen SK (2013) Microbial and physico-chemical analysis of composting process of wheat straw, Indian Journal of Biotechnology 120-128

Peigne J, Girardin P (2004) Environmental impacts of farm-scale composting practices. Water Air Soil Pollut 153(1):45-68.

https://doi.org/10.1023/B:WATE.0000019932.04020.b6

Prakash M, Karmegam N (2010) Vermistabilization of pressmud using Perionyx ceylanensis Mich. Bioresour Technol 101:8464-8468. https://doi.org/10.1016/j.biortech.2010.06.002

Purandaradas A, Silambarasan T, Murugan K, Babujanarthanam R, Gandhi AD, Dhandapani KV, Anbumani D, Kavitha P (2018) Development and quantification of biodiesel production from chicken feather meal as a cost-effective feedstock by using green technology. Biochem Biophys Reports 14:133-139. https://doi.org/10.1016/j.bbrep.2018.04.012

Rakesh S, Poonguzhali S, Saranya B, Suguna S, Jothibasu K (2017) Effect of Panchagavya on Growth and Yield of Abelmoschus esculentus cv, Arka Anamika. International Journal of Current Microbiology Applied Sciences 6:3090-3097. https://doi.org/10.20546/ijcmas.2017.609.380

Rastogi VK (1991) Laser Raman and infrared absorption spectra of 2, 4- dichlornitrobenzene. Acta Phys Pol A 6(79):79, 765-774

Ravindran B, Contreras-Ramos SM, Sekaran G (2015) Changes in earthworm gut associated enzymes and microbial diversity on the treatment of fermented tannery waste using epigeic earthworm Eudrilus eugeniae. Ecol Eng 74:394-401. https://doi.org/10.1016/j.ecoleng.2014.10.014

Ravindran B, Dinesh SL, Kennedy LJ, Sekaran G (2008) Vermicomposting of Solid Waste Generated From Leather Industries Using Epigeic Earthworm Eisenia Foetida. Appl Biochem Biotechnol 151:480-488. https://doi.org/10.1007/s12010-008-8222-3

Ravindran B, Karmegam N, Yuvaraj A, Thangaraj R, Chang SW, Zhang Z, Awasthi MK (2021) Cleaner production of agriculturally valuable benignant materials from industry generated bio-wastes: A review. Biores Technol 320:124281. https://doi.org/10.1016/j.biortech.2020.124281

Salminen E, Rintala J (2002) Anaerobic digestion of organic solid poultry slaughterhouse waste - A review. Bioresour Technol 83:13-26. https://doi.org/10.1016/S0960-8524(01)00199-7

Sarkar S, Kundu SS, Ghorai D (2014) Validation of ancient liquid organics - Panchagavya and Kunapajala as plant growth promoters. Indian J Tradit Knowl 13:398-403

Schwab BS, Ritchie CJ, Kain DJ, Dobrin GC, King LW, Palmisano AC (1994) Characterization of Compost from a Pilot Plant-scale Composter Utilizing Simulated Solid Waste. Waste Manag Res 12(4):289-303. https://doi.org/10.1006/wmre.1994.1019

Selvaraj N (2006) Organic Horticulture: Creating a More Sustainable Farming. Horticultural Research Station. Tamil Nadu Agricultural University

Senthil Kumar D, Satheesh Kumar P, Rajendran NM, Uthaya Kumar V, Anbuganapathi G (2014) Evaluation of vermicompost maturity using scanning electron microscopy and paper chromatography analysis. J Agric Food Chem 62:2738-2741. https://doi.org/10.1021/jf4054403 
Sharma K, Garg VK (2017) Management of food and vegetable processing waste spiked with buffalo waste using earthworms (Eisenia fetida). Environ Sci Pollut Res 24:7829-7836. https://doi.org/10.1007/s11356-017-8438-2

Steve (2017) What Causes Protein Poisoning and What to Do About It. Urbanwormcompany. Web. https://urbanwormcompany.com/what-causes-proteinpoisoning-in-worm-bins/\#comment-3002276 (accessed 3.30.20)

Suthar S (2006) Potential utilization of guar gum industrial waste in vermicompost production. Bioresour Technol 97:2474-2477. https://doi.org/10.1016/j.biortech.2005.10.018

Tesfaye T, Sithole B, Ramjugernath D, Chunilall V (2017) Valorisation of chicken feathers: Characterisation of chemical properties. Waste Manag 68:626635. https://doi.org/10.1016/j.wasman.2017.06.050

Unmar G, Mohee R (2008) Assessing the effect of biodegradable and degradable plastics on the composting of green wastes and compost quality. Bioresour Technol 99(15):6738-6744. https://doi.org/10.1016/j.biortech.2008.01.016

Vasanthi K, Chairman K, Ranjit Singh AJA (2014) Sugar factory waste vermicomposting with an epigeic earthworm, Eudrilus eugeniae (Kinberg). American Journal of Drug Discovery Development 4(1):22-31. https://doi.org/10.3923/ajdd.2014.2231

Vasconcelos A, Freddi G, Cavaco-Paulo A (2008) Biodegradable materials based on silk fibroin and keratin. Biomacromol 9(4):1299-1305. https://doi.org/10.1021/bm7012789

Vasileva-Tonkova E, Gousterova A, Neshev G (2009) Ecologically safe method for improved feather wastes biodegradation. Int Biodeterior Biodegradation 63(8):1008-1012. https://doi.org/10.1016/j.ibiod.2009.07.003

Wang H, Parry DAD, Jones LN, Idler WW, Marekov LN, Steinert PM (2000) In vitro assembly and structure of trichocyte keratin intermediate filaments: A novel role for stabilization by disulfide bonding. J Cell Biol 151:1459-1468. https://doi.org/10.1083/jcb.151.7.1459

Wang K, Qiao Y, Li H, Huang C (2020) Use of integrated biomarker response for studying the resistance strategy of the earthworm Metaphire californica in Cd-contaminated field soils in Hunan Province, South China. Environ Pollut 260:114056. https://doi.org/10.1016/j.envpol.2020.114056

Wojciechowska E, Włochowicz A, Wesełucha-Birczyńska A (1999) Application of Fourier-transform infrared and Raman spectroscopy to study degradation of the wool fiber keratin. J Mol Struct 511:307-318. https://doi.org/10.1016/S0022-2860(99)00173-8

Yuvaraj A, Karmegam N, Thangaraj R (2018) Vermistabilization of paper mill sludge by an epigeic earthworm Perionyx excavatus: mitigation strategies for sustainable environmental management. Ecol Eng 120:187-197. https://doi.org/10.1016/j.ecoleng.2018.06.008

Yuvaraj A, Karmegam N, Tripathi S, Kannan S, Thangaraj R (2020) Environment-friendly management of textile mill wastewater sludge using epigeic earthworms: bioaccumulation of heavy metals and metallothionein production. J Environ Manag 254:109813.

https://doi.org/10.1016/j.jenvman.2019.109813

Zhang BG, Li GT, Shen TS, Wang JK, Sun Z (2000) Changes in microbial biomass C, N, and P and enzyme activities in soil incubated with the earthworms Metaphire guillelmi or Eisenia fetida. Soil Biol Biochem 32:2055-2062. https://doi.org/10.1016/S0038-0717(00)00111-5

\section{Tables}

Table 1 Pre-decomposed panchagavya fortified Chicken feather waste in different concentration ratios

\begin{tabular}{|lll|}
\hline Treatments & Substances $(\mathrm{g} / \mathrm{Kg})$ & Ratio \\
\hline E0 & CFW $:$ CD & $0.000: 1$ \\
\hline E1 & CFW : CD & $0.050: 1$ \\
\hline E2 & CFW : CD & $0.100: 1$ \\
\hline E3 & CFW : CD & $0.200: 1$ \\
\hline E4 & CFW : CD & $0.300: 1$ \\
E5 & CFW : CD & $0.400: 1$ \\
\hline E6 & CFW : CD & $0.500: 1$ \\
\hline
\end{tabular}

CFW - Chicken feathers waste; CD - Cow Dung.

Table 2 Physico-chemical properties of pre-decomposed chicken feather waste 


\begin{tabular}{|c|c|c|c|c|c|c|c|c|c|}
\hline \multirow[t]{2}{*}{ Days } & \multicolumn{3}{|l|}{ T1 } & \multicolumn{3}{|l|}{$\mathrm{T} 2$} & \multicolumn{3}{|l|}{ T3 } \\
\hline & Temp & Moisture & $\mathrm{pH}$ & Temp & Moisture & $\mathrm{pH}$ & Temp & Moisture & $\mathrm{pH}$ \\
\hline 10 & $25.87 \pm 0.45^{b}$ & $85.65 \pm 0.61^{b}$ & $7.69 \pm 0.25^{b}$ & $25.87 \pm 0.68^{c}$ & $83.50 \pm 0.89^{b}$ & $8.61 \pm 0.12^{\mathrm{ab}}$ & $25.00 \pm 0.36^{\mathrm{e}}$ & $75.78 \pm 0.77^{a}$ & $6.51 \pm 0.21^{a}$ \\
\hline 20 & $25.77 \pm 0.61^{b}$ & $88.43 \pm 0.82^{a}$ & $8.14 \pm 0.20^{a}$ & $27.83 \pm 0.50^{\mathrm{bc}}$ & $86.36 \pm 1.10^{a}$ & $9.05 \pm 0.36^{a}$ & $27.80 \pm 0.70^{d}$ & $70.26 \pm 1.64^{b}$ & $6.12 \pm 0.08^{b}$ \\
\hline 30 & $26.13 \pm 0.80^{b}$ & $82.50 \pm 0.93^{c}$ & $7.93 \pm 0.10^{\mathrm{ab}}$ & $27.40 \pm 0.50^{\mathrm{bc}}$ & $81.22 \pm 0.88^{c}$ & $8.62 \pm 0.29^{a b}$ & $31.70 \pm 1.01^{\mathrm{c}}$ & $67.05 \pm 1.67^{c}$ & $6.01 \pm 0.11^{b}$ \\
\hline 40 & $26.87 \pm 0.60^{b}$ & $79.40 \pm 0.77^{e}$ & $8.07 \pm 0.05^{\mathrm{ab}}$ & $27.33 \pm 1.16^{\mathrm{bc}}$ & $81.48 \pm 1.31^{\mathrm{c}}$ & $8.33 \pm 0.16^{b}$ & $39.63 \pm 1.25^{a}$ & $62.09 \pm 1.53^{d}$ & $6.00 \pm 0.19^{b}$ \\
\hline 50 & $28.37 \pm 0.81^{a}$ & $80.75 \pm 0.52^{d}$ & $8.14 \pm 0.42^{\mathrm{a}}$ & $28.23 \pm 1.06^{b}$ & $79.22 \pm 1.02^{d}$ & $8.57 \pm 0.41^{\mathrm{ab}}$ & $35.40 \pm 1.41^{b}$ & $58.87 \pm 0.49^{e}$ & $6.13 \pm 0.07^{b}$ \\
\hline 60 & $29.47 \pm 0.96^{a}$ & $76.21 \pm 0.80^{f}$ & $7.89 \pm 0.15^{a b}$ & $30.23 \pm 1.20^{\mathrm{a}}$ & $73.45 \pm 1.16^{\mathrm{e}}$ & $8.76 \pm 0.26^{\mathrm{ab}}$ & $32.07 \pm 1.55^{c}$ & $58.97 \pm 1.57^{e}$ & $6.16 \pm 0.07^{b}$ \\
\hline $\begin{array}{l}\text { F } \\
\text { Value }\end{array}$ & 13.090 & 101.800 & 1.812 & 5.718 & 50.129 & 2.073 & 64.618 & 73.966 & 5.976 \\
\hline Sig & 0.000 & 0.000 & 0.185 & 0.006 & 0.000 & 0.140 & 0.000 & 0.000 & 0.005 \\
\hline
\end{tabular}

T1- Chicken feather waste with fresh cow dung; T2- Chicken feather waste with dry cow dung; T3- Chicken feather waste with Panchagavya.

Table 3 The average mortality of Eudrilus eugeniae in different ratios of panchagavya fortified chicken feather vermicompost

\begin{tabular}{|c|c|c|c|c|c|c|c|c|c|c|}
\hline \multicolumn{11}{|c|}{ Average Mortality Rate / Days } \\
\hline \multicolumn{2}{|c|}{$1^{\text {st }}$} & \multirow{2}{*}{$\begin{array}{l}2^{\text {nd }} \\
0.00 \pm \\
0.00^{b}\end{array}$} & \multirow{2}{*}{$\begin{array}{l}3^{\text {rd }} \\
0.00 \pm \\
0.00^{b}\end{array}$} & \multirow{2}{*}{$\begin{array}{l}4^{\text {th }} \\
0.00 \pm \\
0.00^{c}\end{array}$} & \multirow{2}{*}{$\begin{array}{l}5^{\text {th }} \\
0.00 \pm \\
0.00^{d}\end{array}$} & \multirow{2}{*}{$\begin{array}{l}6^{\text {th }} \\
0.00 \pm \\
0.00^{d}\end{array}$} & \multirow{2}{*}{$\begin{array}{l}7^{\text {th }} \\
0.00 \pm \\
0.00^{e}\end{array}$} & \multirow{2}{*}{$\begin{array}{l}8^{\text {th }} \\
0.00 \pm \\
0.00^{c}\end{array}$} & \multirow{2}{*}{$\begin{array}{l}9^{\text {th }} \\
0.00 \pm \\
0.00^{\mathrm{b}}\end{array}$} & \multirow{2}{*}{$\begin{array}{l}10^{\text {th }} \\
0.00 \pm \\
0.00^{\mathrm{b}}\end{array}$} \\
\hline E0 & $\begin{array}{l}0.00 \pm \\
0.00^{\mathrm{b}}\end{array}$ & & & & & & & & & \\
\hline E1 & $\begin{array}{l}0.00 \pm \\
0.00^{\mathrm{b}}\end{array}$ & $\begin{array}{l}0.00 \pm \\
0.00^{\mathrm{b}}\end{array}$ & $\begin{array}{l}0.00 \pm \\
0.00^{\mathrm{b}}\end{array}$ & $\begin{array}{l}0.00 \pm \\
0.00^{\mathrm{c}}\end{array}$ & $\begin{array}{l}0.00 \pm \\
0.00^{d}\end{array}$ & $\begin{array}{l}0.00 \pm \\
0.00^{d}\end{array}$ & $\begin{array}{l}0.00 \pm \\
0.00^{\mathrm{e}}\end{array}$ & $\begin{array}{l}0.00 \pm \\
0.00^{\mathrm{c}}\end{array}$ & $\begin{array}{l}0.00 \pm \\
0.00^{\mathrm{b}}\end{array}$ & $\begin{array}{l}0.00 \pm \\
0.00^{\mathrm{b}}\end{array}$ \\
\hline E2 & $\begin{array}{l}0.00 \pm \\
0.00^{\mathrm{b}}\end{array}$ & $\begin{array}{l}0.00 \pm \\
0.00^{\mathrm{b}}\end{array}$ & $\begin{array}{l}0.00 \pm \\
0.00^{\mathrm{b}}\end{array}$ & $\begin{array}{l}0.67 \pm \\
0.67^{c}\end{array}$ & $\begin{array}{l}4.00 \pm \\
0.58^{\mathrm{cd}}\end{array}$ & $\begin{array}{l}8.33 \pm \\
1.20^{c}\end{array}$ & $\begin{array}{l}13.67 \pm \\
2.03^{d}\end{array}$ & $\begin{array}{l}20.33 \pm \\
2.19^{b}\end{array}$ & $\begin{array}{l}23.00 \pm \\
1.15^{\mathrm{a}}\end{array}$ & $\begin{array}{l}24.67 \pm \\
0.33^{a}\end{array}$ \\
\hline E3 & $\begin{array}{l}0.00 \pm \\
0.00^{\mathrm{b}}\end{array}$ & $\begin{array}{l}0.00 \pm \\
0.00^{\mathrm{b}}\end{array}$ & $\begin{array}{l}0.67 \pm \\
0.67^{b}\end{array}$ & $\begin{array}{l}3.67 \pm \\
2.33^{\mathrm{bc}}\end{array}$ & $\begin{array}{l}7.67 \pm \\
2.73^{b c}\end{array}$ & $\begin{array}{l}12.00 \pm \\
2.31^{b c}\end{array}$ & $\begin{array}{l}17.33 \pm \\
2.03^{\mathrm{cd}}\end{array}$ & $\begin{array}{l}20.33 \pm \\
1.76^{b}\end{array}$ & $\begin{array}{l}23.00 \pm \\
2.00^{a}\end{array}$ & $\begin{array}{l}25.00 \pm \\
0.00^{\mathrm{a}}\end{array}$ \\
\hline E4 & $\begin{array}{l}0.00 \pm \\
0.00^{\mathrm{b}}\end{array}$ & $\begin{array}{l}0.00 \pm \\
0.00^{\mathrm{b}}\end{array}$ & $\begin{array}{l}1.67 \pm \\
1.67^{\mathrm{b}}\end{array}$ & $\begin{array}{l}7.67 \pm \\
0.88^{a b}\end{array}$ & $\begin{array}{l}12.33 \pm \\
1.76^{\mathrm{ab}}\end{array}$ & $\begin{array}{l}17.67 \pm \\
1.33^{a}\end{array}$ & $\begin{array}{l}21.67 \pm \\
1.33^{\mathrm{ab}}\end{array}$ & $\begin{array}{l}23.67 \pm \\
0.88^{a b}\end{array}$ & $\begin{array}{l}25.00 \pm \\
0.00^{a}\end{array}$ & $\begin{array}{l}25.00 \pm \\
0.00^{\mathrm{a}}\end{array}$ \\
\hline E5 & $\begin{array}{l}1.00 \pm \\
0.58^{\mathrm{ab}}\end{array}$ & $\begin{array}{l}2.33 \pm \\
0.67^{b}\end{array}$ & $\begin{array}{l}5.00 \pm \\
0.58^{a}\end{array}$ & $\begin{array}{l}11.33 \pm \\
1.86^{a}\end{array}$ & $\begin{array}{l}14.33 \pm \\
2.60^{a}\end{array}$ & $\begin{array}{l}18.67 \pm \\
2.19^{a}\end{array}$ & $\begin{array}{l}22.33 \pm \\
1.33^{a}\end{array}$ & $\begin{array}{l}24.67 \pm \\
0.33^{a}\end{array}$ & $\begin{array}{l}25.00 \pm \\
0.00^{a}\end{array}$ & $\begin{array}{l}25.00 \pm \\
0.00^{\mathrm{a}}\end{array}$ \\
\hline E6 & $\begin{array}{l}1.67 \pm \\
0.88^{a}\end{array}$ & $\begin{array}{l}3.00 \pm \\
1.15^{\mathrm{a}}\end{array}$ & $\begin{array}{l}4.67 \pm \\
1.45^{a}\end{array}$ & $\begin{array}{l}7.67 \pm \\
1.45^{\mathrm{ab}}\end{array}$ & $\begin{array}{l}11.33 \pm \\
2.03^{\mathrm{ab}}\end{array}$ & $\begin{array}{l}15.00 \pm \\
1.00^{\mathrm{ab}}\end{array}$ & $\begin{array}{l}18.00 \pm \\
0.58^{b c}\end{array}$ & $\begin{array}{l}20.67 \pm \\
0.88^{b}\end{array}$ & $\begin{array}{l}24.00 \pm \\
1.00^{\mathrm{a}}\end{array}$ & $\begin{array}{l}25.00 \pm \\
0.00^{\mathrm{a}}\end{array}$ \\
\hline $\mathrm{F}$ & 2.90 & 6.81 & 6.05 & 11.70 & 11.16 & 29.73 & 52.39 & 86.00 & 152.31 & 9326.00 \\
\hline Sig & 0.04 & 0.00 & 0.00 & 0.00 & 0.00 & 0.00 & 0.00 & 0.00 & 0.00 & 0.00 \\
\hline
\end{tabular}

Table 4 Physico-chemical parameters in different ratios of panchagavya fortified chicken feather vermicompost 


\begin{tabular}{|llllll|}
\hline Experiments & $\mathrm{pH}$ & Moisture (\%) & Organic Matter (\%) & Organic Carbon (\%) & Ash (\%) \\
\hline E0 & $6.67 \pm 0.14^{\mathrm{c}}$ & $56.89 \pm 4.75^{\mathrm{d}}$ & $40.45 \pm 1.68^{\mathrm{bc}}$ & $23.52 \pm 0.97^{\mathrm{bc}}$ & $57.67 \pm 1.75^{\mathrm{ab}}$ \\
\hline E1 & $7.42 \pm 0.16^{\mathrm{ab}}$ & $67.83 \pm 2.76^{\mathrm{bc}}$ & $44.52 \pm 4.00^{\mathrm{a}}$ & $25.89 \pm 2.33^{\mathrm{ab}}$ & $53.40 \pm 4.19^{\mathrm{bc}}$ \\
\hline E2 & $7.49 \pm 0.16^{\mathrm{a}}$ & $68.51 \pm 1.12^{\mathrm{b}}$ & $43.76 \pm 1.18^{\mathrm{ab}}$ & $25.31 \pm 0.71^{\mathrm{ab}}$ & $54.21 \pm 2.47^{\mathrm{bc}}$ \\
\hline E3 & $7.18 \pm 0.05^{\mathrm{b}}$ & $71.34 \pm 1.14^{\mathrm{b}}$ & $47.45 \pm 2.49^{\mathrm{a}}$ & $26.47 \pm 1.25^{\mathrm{a}}$ & $51.48 \pm 1.78^{\mathrm{c}}$ \\
\hline E4 & $6.67 \pm 0.21^{\mathrm{c}}$ & $63.91 \pm 0.68^{\mathrm{c}}$ & $45.46 \pm 0.99^{\mathrm{a}}$ & $25.76 \pm 1.20^{\mathrm{ab}}$ & $54.27 \pm 1.97^{\mathrm{bc}}$ \\
\hline E5 & $5.74 \pm 0.08^{\mathrm{e}}$ & $75.77 \pm 0.73^{\mathrm{a}}$ & $43.71 \pm 1.64^{\mathrm{ab}}$ & $24.50 \pm 1.16^{\mathrm{abc}}$ & $56.46 \pm 0.88^{\mathrm{ab}}$ \\
\hline E6 & $6.30 \pm 0.23^{\mathrm{d}}$ & $68.07 \pm 2.52^{\mathrm{bc}}$ & $37.90 \pm 1.16^{\mathrm{c}}$ & $22.53 \pm 0.80^{\mathrm{c}}$ & $59.25 \pm 1.40^{\mathrm{a}}$ \\
\hline F Value & 47.448 & 18.348 & 6.800 & 3.548 & 4.124 \\
\hline Sig & 0.000 & 0.000 & 0.002 & 0.024 & 0.014 \\
\hline
\end{tabular}

Table 5 Elemental analysis using energy dispersive spectroscopy of panchagavya fortified chicken feather vermicompost

\begin{tabular}{|c|c|c|c|c|c|c|c|c|c|c|c|c|c|c|}
\hline & E0 & & E1 & & E2 & & E3 & & E4 & & E5 & & E6 & \\
\hline & Wet. \% & At. \% & Wet. \% & At. \% & Wet. \% & At. \% & Wet. \% & At. \% & Wet. \% & At. \% & Wet. \% & At. $\%$ & Wet. \% & At. \% \\
\hline $\mathrm{Ca}$ & 18.69 & 12.48 & 55.64 & 39.18 & 7.10 & 3.72 & 13.45 & 6.04 & 30.12 & 15.75 & 5.69 & 2.93 & 12.79 & 5.91 \\
\hline C & 9.58 & 21.34 & 10.74 & 25.25 & 24.38 & 42.62 & 34.48 & 51.63 & 25.28 & 44.12 & 13.34 & 22.97 & 27.94 & 43.06 \\
\hline $\mathrm{Si}$ & 33.64 & 32.05 & 8.89 & 8.93 & 46.54 & 34.80 & 3.31 & 2.12 & 4.69 & 3.50 & 36.95 & 27.21 & 14.87 & 9.80 \\
\hline 0 & 6.67 & 11.16 & 7.86 & 13.86 & 9.54 & 12.52 & 27.87 & 31.33 & 17.63 & 23.10 & 30.46 & 39.38 & 27.32 & 31.61 \\
\hline $\mathrm{K}$ & 7.43 & 5.09 & 4.42 & 3.19 & 3.34 & 1.80 & 4.80 & 2.21 & 6.02 & 3.23 & 6.94 & 3.67 & 2.78 & 1.32 \\
\hline $\mathrm{Cl}$ & 10.67 & 8.06 & 2.74 & 2.18 & 2.13 & 1.26 & 4.96 & 2.52 & 7.14 & 4.22 & 1.59 & 0.93 & 2.47 & 1.29 \\
\hline Mo & - & - & - & - & - & - & 5.70 & 1.07 & - & - & - & - & - & - \\
\hline $\mathrm{Fe}$ & 3.13 & 1.50 & 6.52 & 3.30 & 5.57 & 2.10 & 0.66 & 0.21 & 2.79 & 1.05 & 2.19 & 0.81 & 2.94 & 0.98 \\
\hline $\mathrm{P}$ & 4.33 & 3.74 & 0.55 & 0.50 & - & - & 2.93 & 1.70 & 1.13 & 0.76 & 0.97 & 0.65 & 1.95 & 1.17 \\
\hline $\mathrm{Na}$ & - & - & - & - & 0.39 & 0.36 & - & - & 1.03 & 0.94 & - & - & 0.68 & 0.54 \\
\hline Al & - & - & - & - & 0.36 & 0.28 & - & - & - & - & - & - & - & - \\
\hline $\mathrm{Mg}$ & - & - & - & - & 0.64 & 0.55 & 1.10 & 0.81 & 0.92 & 0.79 & 1.20 & 1.02 & 4.42 & 3.37 \\
\hline $\mathrm{N}$ & - & - & 1.24 & 2.51 & - & - & - & - & 0.60 & 0.89 & - & - & - & - \\
\hline $\mathrm{Ti}$ & - & - & - & - & - & - & 0.27 & 0.10 & - & - & - & - & - & - \\
\hline$S$ & 4.94 & 4.13 & 1.08 & 0.95 & - & - & 0.46 & 0.26 & - & - & 0.60 & 0.39 & 1.39 & 0.80 \\
\hline $\mathrm{Mn}$ & 0.34 & 0.16 & 0.33 & 0.17 & - & - & - & - & 0.36 & 0.14 & - & - & 0.29 & 0.10 \\
\hline $\mathrm{Cr}$ & 0.58 & 0.30 & - & - & - & - & - & - & - & - & - & - & 0.16 & 0.06 \\
\hline Co & - & - & - & - & - & - & - & - & - & - & 0.08 & 0.03 & - & - \\
\hline
\end{tabular}

\section{Figures}




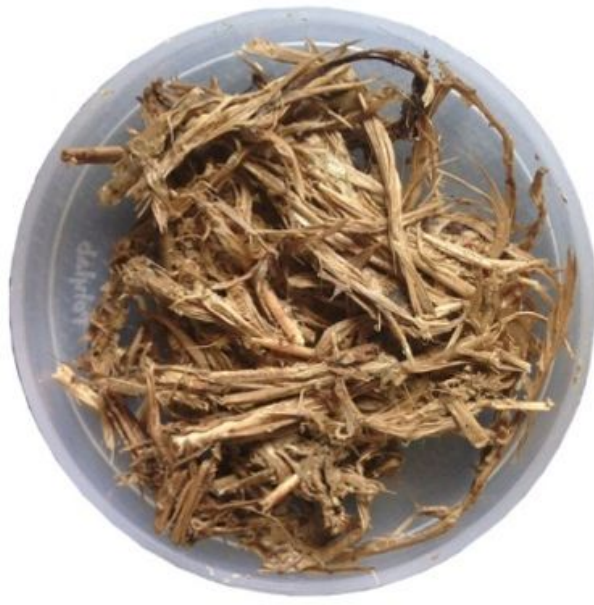

T1

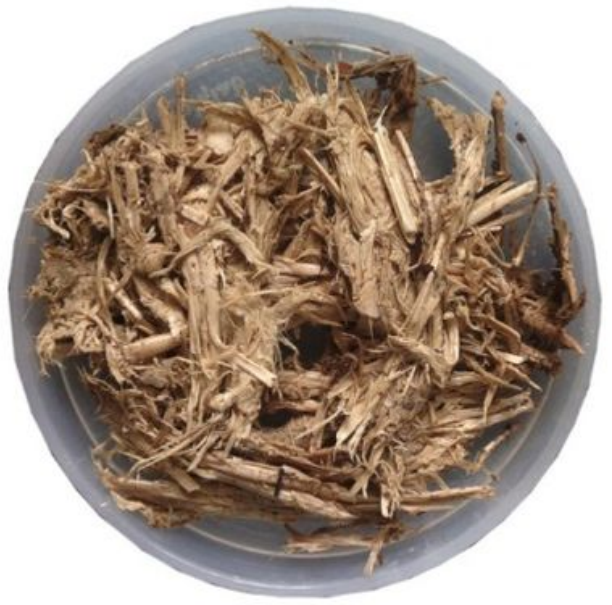

T2

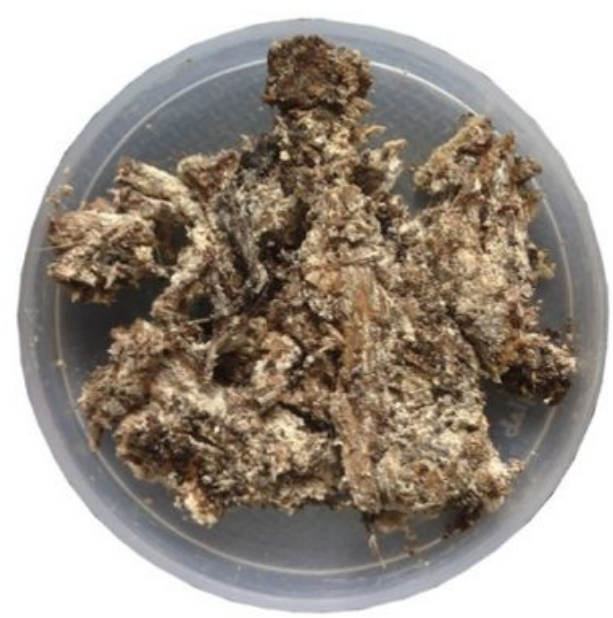

T3

\section{Figure 1}

Pre-decomposition of chicken feather waste materials in different treatments. T1- chicken feather waste with fresh cow dung; T2 - Chicken feather waste with dry cow dung; T3 -Chicken feather waste with Panchagavya.
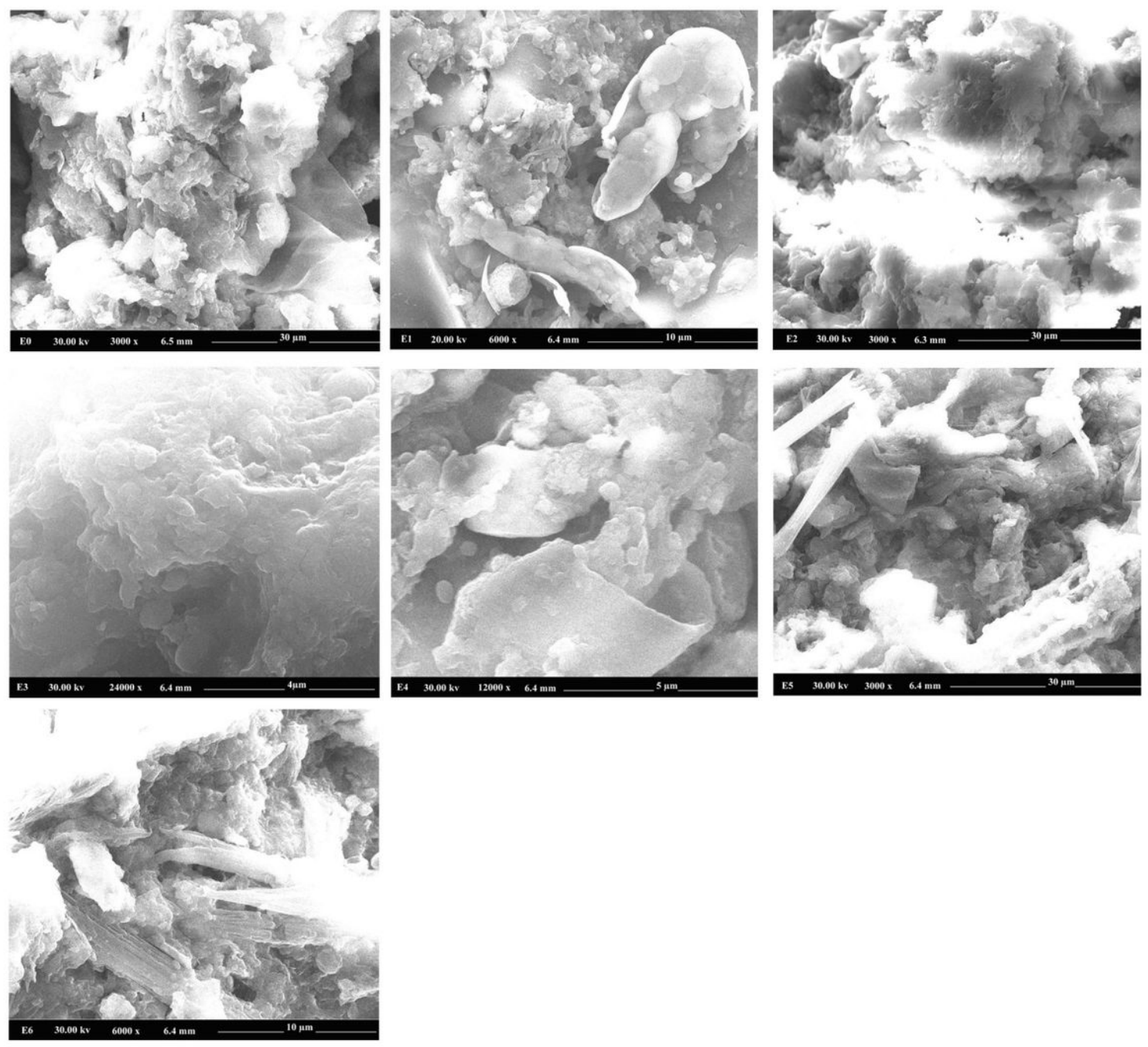

Figure 2 


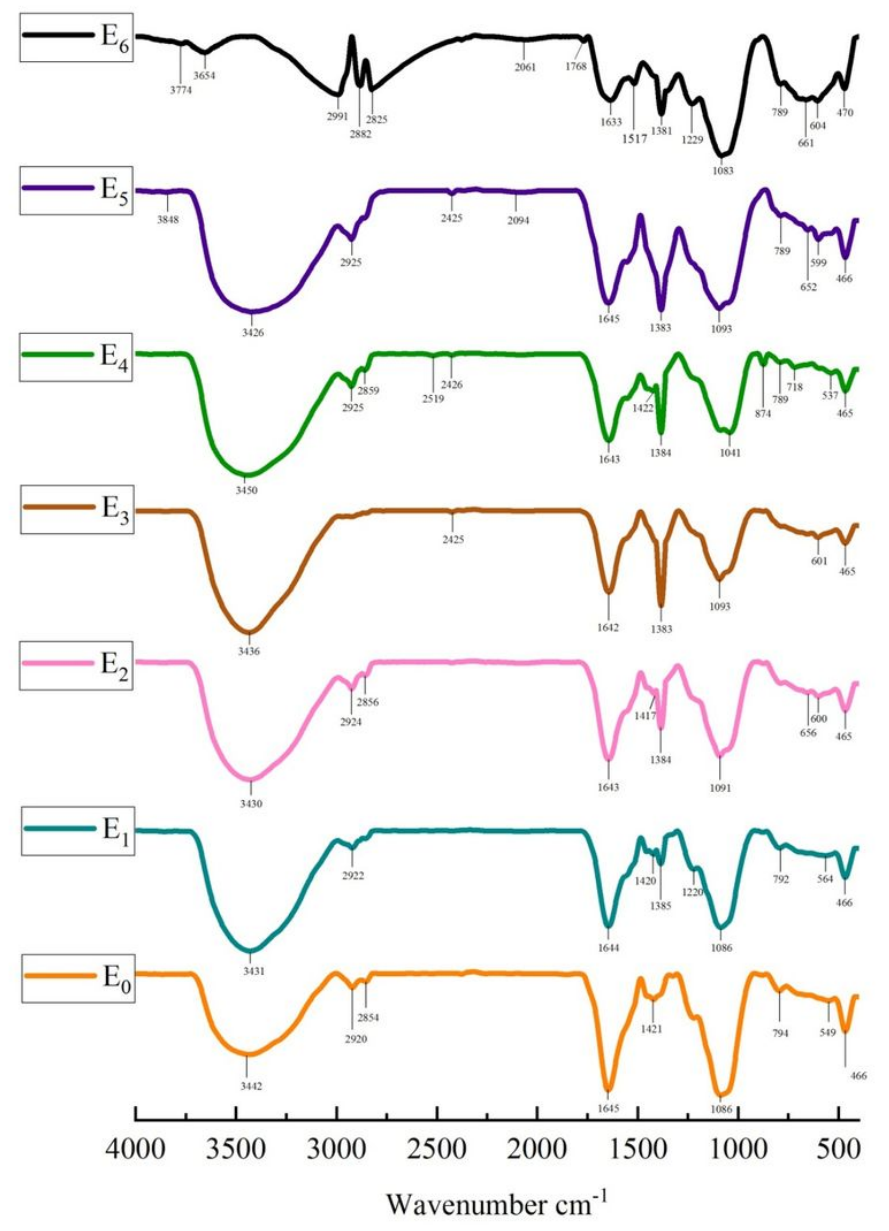

Figure 3

FT-IR analysis of panchagavya fortified chicken feather vermicompost at different ratios. 